\title{
On Seasonal Fluctuations of Available Olsen P in Soils
}

\author{
Vincenzo Tabaglio*, Carolina Gavazzi, Paolo Paris \\ Istituto di Agronomia generale e coltivazioni erbacee, Università Cattolica del S. Cuore \\ Via Emilia Parmense 84, 29100 Piacenza, Italy
}

Received: 20 October 2003. Accepted: 21 March 2005

\begin{abstract}
The likelihood of a strong seasonal effect on the analytical results of soil chemical tests has been substantiated by several findings. The occurrence of such a trouble would heavily affect the routine work of chemical laboratories dealing with hundreds or thousands of soil samples every year and would possibly interfere even with current timing of soil sampling and testing in agronomical research. Soils from four different experimental fields were sampled and analyzed for Olsen P test through the growing season of both spring-summer crops (maize) and autumn-spring crops (soft wheat). To avoid the cross effect of recent P applications, samples were collected only from the control plots, with no P applied. In a first long-time experiment the level of Olsen P was followed in three soils during two years, while in a second experiment the study considered two different soils for a couple of years each. The amount of extractable (available) Olsen P showed significant fluctuations-with-time in four years out of six. The observed variations seems entirely due to $\mathrm{P}$ absorption by crops, as they appeared in the final samplings during the cropping season. The amount of decrease was nearly always small, less than 1-1.5 mg kg-1 soil, and consistent with the reduction of the available pool which is to be expected as crops gradually take up nutrients. As far as Olsen P is concerned, no evidence was found for the occurrence of erratic seasonal variations such as those previously reported. As soil samples for advisory purposes are usually taken at different times of the year, it seems reassuring that no complications are to be expected about information needed to interpret the results of chemical tests.
\end{abstract}

Key-words: Olsen P, chemical test, seasonal fluctuation.

\section{Introduction}

For many years, most agricultural experimentation regarding plant production has made periodic use of soil testing in order to trace the availability of the main plant nutrients. The analytical results of chemical soil tests are usually correlated with either yield performance, or growth rate, or restricted shoot growth of crops.

A vital condition of such an approach is the reliability of the data so obtained, around which both the meaning and usefulness of the research hinge. In this context, the critical role played by the variability of the physical and chemical properties of soils appears obvious. This variability could take either the form of a spatial heterogeneity or of a fluctuation through time.

Only the second feature will be considered here, that is the possible seasonal variation that is known to affect several soil properties. It seems appropriate to underline that this aspect deserves a great deal of interest if one pays attention to the needs of a laboratory for chemical analyses. Here, an optimal productivity schedule is required, owing to the high costs of instrumentation and workforce, and therefore a prolonged period of activity is needed in order to maximize the number of soil samples to be analyzed each year. To exemplify, one or more teams of field samplers should be able to supply the lab with a steady stream of soil samples each month to meet the working capacity of the lab. Field recognition and sampling should, therefore, be continued for as long as possible, well over a single season, to allow an economic running of the lab.

A significant mass of research concerning 
the instability of many soil parameters through time is already available in the literature (Read and Cameron, 1979; Weaver and Forcella, 1979; Chien et al., 1982; Kuo and Jellum, 1987).

It seems obvious that several soil properties will be affected by fluctuations during, say, one year or a single growth period. It may be the case of $\mathrm{N}$ or $\mathrm{K}$ availability, which depends strongly on biological activity of soil; it may be as well the case of many meteorological influences on $\mathrm{pH}$, or on nitrate leaching or accumulation (Peterson and Rolfe, 1982; Lundell, 1987).

Soil parameters' fluctuations may also be the result of dynamic aspects concerning nutrients such as the easily exchangeable $\mathrm{K}$ that is often replenished by slowly exchangeable $\mathrm{K}$ or by release of interlayer-K (Beckett, 1987).

Many of these processes have been convincingly documented through intensive soil sampling and testing during the seasons of one or more years. Some of the papers concerning $\mathrm{P}$ fluctuations will be briefly recalled below.

Smith (1959) reported very large variations in "easily extractable phosphorus" (no further specification given), something between 29 and $139 \mathrm{mg} \mathrm{P} \mathrm{kg}^{-1}$ soil. The high figure, which may be regarded as an occasional finding since it was recorded only one time in four years, came from a sample taken during a warmer than usual summer. Considering the data published by Smith one could wisely decide that summer and autumn samplings are best avoided.

Blakemore (1966) examined seasonal variation sampling soils at monthly intervals on several sites of the classical experiments at Rothamsted and Woburn; soil samples were taken both from plots dressed each year and from plots without any fertilizer addition. Shaking the soil samples with a $0.01 \mathrm{M} \mathrm{CaCl}_{2}$ solution led to significant fluctuations of $\mathrm{P}$ and $\mathrm{K}$ extracted from plots yearly treated with farmyard manure or phosphate, potash and other nutrients, while fluctuations were very small for the plots maintained without any nutrient supply.

Garbouchev (1966) used both $0.01 \mathrm{M} \mathrm{CaCl}_{2}$ extraction and an anion-exchange resin to determine an "exchangeable" form of P. He took into consideration several crop-soil combinations of the classical experiments at Rothamsted, Woburn and Saxmundham and sampled soils from both fertilized and unfertilized plots between May 1963 and April 1964, at monthly in- tervals. To narrow down the mass of results he obtained, $\mathrm{P}$ excheangeable from the unfertilized plots under sugar beet at Woburn showed large variations, between $12.5 \mathrm{mg} \mathrm{kg}^{-1}$ in November and $39.5 \mathrm{mg} \mathrm{kg}^{-1}$ in February. At the same site, similar, though smaller, fluctuations were observed under grass-clover leys. At Rothamsted, analytical values for soils under kale and ley were definitely more stable, around $3.5-4.5 \mathrm{mg}$ $\mathrm{kg}^{-1}$ through the year. The same held for soils under barley and peas, at Saxmundham.

Ball and Williams (1968) explored several uncultivated brown earths to study the occurrence of both spatial variability and seasonal variation, with weekly sampling of soil for 22 weeks from May to October. As for acetic acidextractable $\mathrm{P}$, fluctuations through time were so small that no trend was detectable.

All these findings have a rather local meaning, since extrapolation cannot properly weigh the role of factors specifically effective in each single case and decisive in determining the trend of the given variable.

Some authors looked into the occurrence of seasonal variations of chemical parameters after fertilizers and other manures are added to the soils (Lamarre and Payette, 1989). Their results seem foregone and barely worth mentioning; at most, they describe individual cases but cannot predict trends recurrent in all the possible circumstances.

Beyond any doubt, the magnitude of these seasonal fluctuations in agricultural soils may heavily influence the reliability of chemical tests, whether they are from samples taken once in a while or periodically. The Emilia-Romagna Region, for instance, has launched an expensive programme aimed to bring under survey agricultural soils and supply technical advice to the farmer. But it was never ascertained whether the sampling schedule throughout the year is subject to difficult interpretations due to seasonal variability of chemical parameters. Even a strict standardization of the soil sampling procedure might be an ineffective measure of analysis, as crops' growth rhythms may be affected by nutrient concentrations that are present in the soil during certain periods may be different from those assessed during a given sampling date and analysis (Esilaba et al., 1992; Cavazza and Patruno, 1997; 1998).

As for phosphorus, a fluctuation of its avail- 
ability due to meteorological influences, particularly rainfall pattern, is to be considered unlikely as far as native, and not recently applied, $\mathrm{P}$ is concerned. Some indirect influence could spring either from $\mathrm{pH}$ variations capable to modify the equilibrium among different $\mathrm{P}$ pools, or from altered availability of $\mathrm{Ca}$ from carbonates which could affect $\mathrm{P}$ extractability too, at least by the Olsen method.

The possible practical role of seasonal patterns in the Olsen $\mathrm{P}$ was examined in the course of a long-term experiment conducted by our Institute on the re-use of $\mathrm{P}$ reserves (Paris et al., 1997; Tabaglio and Gavazzi, 2003) and during another field study on the nitrate formation in the agricultural soils (Tabaglio and Ligabue, 2001).

\section{Materials and methods}

The results of four experiments belonging to two different research programmes developed between 1987 and 2000 are presented here.

\section{$2.11^{\text {st }}$ Programme - Experiments 1 and 2}

A long-term experiment on the reutilization and depletion of phosphate reserves was conducted on some soil types of Emilia-Romagna. The main results have been published in two reports by Paris et al. (1997) and Tabaglio and Gavazzi (2003). During the first few years of this research program that lasted fifteen years, starting in 1987, a preliminary aim was to ascertain the possible occurrence of seasonal fluctuations in P Olsen values. The possible appearance of large variations of this parameter could have indeed endangered the scope of the whole programme that was centered on an agronomic balance sheet of $\mathrm{P}$ supply and removal by a series of crops.

The field study took into account three soils types which resulted rich in Olsen P. The sites were Quarantoli (MO), Taneto (RE) and Gariga (PC), and were selected following the advice of pedologists from the Ufficio Cartografico Emilia Romagna Region. The main soil properties are summarized in Table 1.

At each site, a randomized complete block design with 12 replications was established, cropped with maize for a number of years, under three P levels: an unfertilized treatment (P0, control) was placed side by side with an annual rate of $\mathrm{P}$ balancing $\mathrm{P}$ uptake by crop (P1, 26.2 $\mathrm{kg} \mathrm{P} \mathrm{ha-1} \mathrm{y}^{-1}$ as superphosphate) and with a second rate of $\mathrm{P}$ doubling the previous $(\mathrm{P} 2,52.4$ $\left.\mathrm{kg} \mathrm{P} \mathrm{ha-1} \mathrm{y}^{-1}\right)$. The plot area was $35-40 \mathrm{~m}^{2}$.

In these locations two series of controls were performed on the $\mathrm{P} 0$ treatments only, in order to detect possible seasonal fluctuations of Olsen P.

Experiment 1 - Between April and October 1987, 24 subplots (P0 treatment) were sampled in each field, on three occasions distributed over three seasons, totalizing 216 soil samples. Each sample was from three soil cores taken at 0-30 cm depth.

Experiment 2 - On three occasions during 1989, on the same fields, six P0 plots were sampled to verify the available $\mathrm{P}$ spatial variability. Each plot was split into ten subareas, each of them individually sampled and analyzed for spatial heterogenity (data not published). For the present survey on the seasonal fluctuations, four out of ten subareas were randomly selected as subplots. Totally, 216 samples have been analyzed for Olsen $\mathrm{P}$ availability. The operating procedure was the same as reported above.

\section{$2.22^{\text {nd }}$ Programme - Experiments 3 and 4}

Another research project concerning the genesis, transformation and migration of nitrates from soil to surface and ground water, was developed by C.R.P.A. Foundation for agricultural studies and research, Reggio Emilia, jointly with the Institute of General Agronomy and Field Crops, Catholic University, Piacenza. Within the frame of these activities, two out of several experimental fields were chosen for repetition of the investigation on the possible fluctuation of Olsen P, taking advantage of the monthly soil sampling frequency needed to follow the trend of nitrates.

The sites were located: (i) near Villa Gaida (RE) on a farm owned by Istituto Professionale per l'agricoltura "A. Motti"; (ii) near Formigine (MO) on the "Stradella" farm. For short, from now on they will be referred to as $\mathrm{RE}$ and MO. The main properties of these soils too are shown in Table 1.

Olsen P was analyzed for two years: during 1996-97 and 1997-98 as far as RE is concerned (experiment 3) and during 1998-99 and 19992000 for MO (experiment 4). Winter wheat was always cropped at both sites. 
Table 1. Main properties of experimental soils.

\begin{tabular}{|c|c|c|c|c|c|}
\hline Property & $\begin{array}{l}\text { Quarantoli } \\
\text { (MO) }\end{array}$ & $\begin{array}{c}\text { Taneto } \\
\text { (RE) }\end{array}$ & $\begin{array}{l}\text { Gariga } \\
\text { (PC) }\end{array}$ & $\begin{array}{l}\text { Villa Gaida } \\
\text { (RE) }\end{array}$ & $\begin{array}{l}\text { Formigine } \\
\text { (MO) }\end{array}$ \\
\hline sand $(2-0.05 \mathrm{~mm}), \%$ & 25.3 & 9.3 & 9.2 & 18.6 & 14.6 \\
\hline silt $(0.05-0.002 \mathrm{~mm}), \%$ & 45.6 & 45.2 & 68.5 & 44.0 & 55.0 \\
\hline clay $(<0.002 \mathrm{~mm}), \%$ & 29.1 & 45.5 & 22.3 & 37.4 & 30.4 \\
\hline $\mathrm{pH}\left(\mathrm{CaCl}_{2} 0.01 \mathrm{M}\right)$ & 7.6 & 7.5 & 6.4 & 7.1 & 7.0 \\
\hline organic matter (Walkley and Black), \% & 1.98 & 3.21 & 1.46 & 2.20 & 2.30 \\
\hline total N (Kjeldahl), \% & 0.124 & 0.194 & 0.101 & 0.142 & 0.165 \\
\hline Olsen $\mathrm{P}\left(\mathrm{NaHCO}_{3} 0.5 \mathrm{M}, \mathrm{pH} 8.5\right), \mathrm{mg} \mathrm{kg}^{-1}$ & 23.1 & 23.2 & 37.9 & 12.0 & 15.1 \\
\hline
\end{tabular}

The layout of the trials was a $4 \times 4$ latin square with four $\mathrm{N}$ treatments (N0-N1-N2-N3) and four blocks. After a preliminary check to verify the unlikely influence of $\mathrm{N}$ rates on Olsen $\mathrm{P}$ levels, only the N0 plots were taken into consideration. Each time, four cores of soil down to plough depth $(0-25 \mathrm{~cm})$ were mixed to make up the sample from a $40 \mathrm{~m}^{2}$ single plot. Totally, 48 samples have been analyzed.

All the experimental soils have been classified according to Soil Taxonomy as Ustochrepts; the Quarantoli (MO) and the Formigine sites are Udifluventic Ustochrepts; the Taneto (RE) and Villa Gaida (RE) sites are Udertic Ustochrepts and the Gariga (PC) site is Udic Ustochrepts (Soil Survey Staff, 1992).

With the aim to obtain maximum resolution for the "date of sampling" variable, statistical analysis was conducted as follows:

- experiment 1: split-plot with order of factors:

(i) location; (ii) block; (iii) date of sampling;

- experiment 2: split-split-plot with: (i) location; (ii) block; (iii) treatment (subplot); (iiii) date of sampling;

- experiments 3 and 4: fully randomized blocks. Chemical analysis was performed according to the Olsen method (Olsen et al., 1954) with cold colour development (i.e. K antimonium tartrate, Olsen and Sommers, 1982).

\section{Results and discussion}

\subsection{Experiment 1}

Table 2 brings together the essential results obtained in the three experimental fields, showing the lack of seasonal fluctuations.

One can find two types of statistical significance. First of all, a neat difference among field means reflects the original differences existing at the beginning of the research; two out of three fields show similar values, while the third one (Gariga, PC) is clearly richer in available P. A second significant factor is the general mean for the date of sampling, where there appears a small reduction $(\mathrm{P}=0.05)$ at the end of the growing season. Such a decline seems reasonably connected with $\mathrm{P}$ uptake by crops, rather than with seasonal fluctuations. No variation appeared connected with the date of sampling.

\subsection{Experiment 2}

During the third year of the same long-term field research, soils from spring, summer and autumn sampling showed significant variations of the Olsen P level due to the date of sampling (Table 3 ). As with experiment 1 , the soil analysis shows clear differences in the availability of $P$ levels between location means, although with values lower than at the start, due to $\mathrm{P}$ taken up by three consecutive crops.

On the contrary, the date of sampling means

Table 2. Olsen $\mathrm{P}$ concentrations of soils in Experiment $1\left(\mathrm{P}, \mathrm{mg} \mathrm{kg}^{-1}\right)$.

\begin{tabular}{|c|c|c|c|c|c|c|c|}
\hline \multirow{3}{*}{ Sampling } & \multicolumn{6}{|c|}{ Location } & \multirow{3}{*}{$\begin{array}{c}\text { Sampling } \\
\text { mean }\end{array}$} \\
\hline & \multicolumn{2}{|c|}{ Quarantoli } & \multicolumn{2}{|c|}{ Taneto } & \multicolumn{2}{|c|}{ Gariga } & \\
\hline & date & Olsen P & date & Olsen P & date & Olsen P & \\
\hline Spring 1987 & 23 April & 23.3 & 20 April & 21.0 & 16 April & 36.0 & $26.8 \mathrm{~b} \mathrm{~A}$ \\
\hline Summer 1987 & 2 July & 23.6 & 30 June & 21.9 & 23 June & 33.1 & $26.2 \mathrm{~b} \mathrm{~A}$ \\
\hline Autumn 1987 & 20 October & 20.1 & 21 October & 20.1 & 26 October & 34.5 & 24.9 a $\mathrm{A}$ \\
\hline Location mean & \multicolumn{2}{|c|}{22.3 a $\mathrm{A}$} & \multicolumn{2}{|c|}{$21.0 \mathrm{a} \mathrm{A}$} & \multicolumn{2}{|c|}{$34.5 \mathrm{~b} \mathrm{~B}$} & \\
\hline
\end{tabular}


Table 3. Olsen $\mathrm{P}$ concentrations of soils in Experiment $2\left(\mathrm{P}, \mathrm{mg} \mathrm{kg}^{-1}\right)$.

\begin{tabular}{lccccccc}
\hline \multirow{2}{*}{ Sampling } & \multicolumn{9}{c}{ Location } & & \multicolumn{2}{c}{ Gariga } & Sampling \\
mean
\end{tabular}

were statistically significant, with values of the second and the third sampling being similar to each other but lower than the first one at both probability levels. It is worthwhile noticing that the differences remain quite small, being $<1 \mathrm{mg}$ $\mathrm{kg}^{-1}$ and point to a progressive reduction of the Olsen P level. They do not appear to indicate an erratic fluctuation of the results, as sometimes the literature has suggested.

In both experiments, Olsen P level is affected by a location $\times$ date of sampling interaction, at $\mathrm{P}=0.001$. The Gariga soil, much richer in available $\mathrm{P}$, shows an increase at the end of growing season, whereas the other two soils reduce their Olsen $\mathrm{P}$ more and more.

\subsection{Experiment 3}

The study of soils far less supplied with available $\mathrm{P}$ and to winter crops (Table 4) shows that at Villa Gaida (RE) the analytical results did not reach statistical significance for the $\mathrm{F}$ test in the first year while slight differences were assessed for the three dates of sampling in the sec- ond year (1997-98). Actually, even in this case the data show small fluctuations that, in the second year, obtain a significance only by comparing winter and spring sampling.

The results of the analysis do not support the hypothesis that during the growth period a set of processes may have caused variations in $\mathrm{P}$ extractability according to the Olsen method, given that the effects of $\mathrm{P}$ absorbed by wheat are confounded in the spring sampling.

\subsection{Experiment 4}

Also in this last series of investigations one can find the same trend just annotated for experiment 3 . The results of the first year analysis did not find any statistical significance. The means for the sampling dates of the second crop came out rather different $(\mathrm{P}=0.05)$, and the last year control, taken in spring, gave lower figures than those of the previous autumn and winter sampling.

Even for this experiment it seems impossible to conclude that $\mathrm{P}$ availability may have

Table 4. Olsen P concentrations of Villa Gaida soil in Experiment $3\left(\mathrm{P}, \mathrm{mg} \mathrm{kg}^{-1}\right)$.

\begin{tabular}{|c|c|c|c|c|}
\hline \multirow[t]{2}{*}{ Sampling } & \multicolumn{2}{|c|}{$1996-97$} & \multicolumn{2}{|c|}{$1997-98$} \\
\hline & date & Olsen P & date & Olsen P \\
\hline Autumn & 4 November & 6.7 & 10 November & $6.5 \mathrm{ab} \mathrm{AB}$ \\
\hline Winter & 17 February & 7.8 & 11 February & 7.6 b $\quad$ B \\
\hline Spring & 22 May & 6.5 & 13 May & 5.6 a $\mathrm{A}$ \\
\hline Variance analysis & \multicolumn{2}{|c|}{ NS } & \multicolumn{2}{|c|}{$\mathrm{F}$ significant at $\mathrm{P}=0.05$} \\
\hline
\end{tabular}

Table 5. Olsen $\mathrm{P}$ concentrations of Formigine soil in Experiment $4\left(\mathrm{P}, \mathrm{mg} \mathrm{kg}^{-1}\right)$.

\begin{tabular}{lcccc}
\hline Sampling & \multicolumn{2}{c}{$1998-99$} & \multicolumn{2}{c}{$1999-2000$} \\
\cline { 2 - 5 } & date & Olsen P & date & Olsen P \\
\hline Autumn & 29 October & 11.7 & 10 November & 9.0 b A \\
Winter & 9 February & 10.0 & 18 February & 9.1 b A \\
Spring & 11 May & 9.3 & 18 May & 6.8 a A \\
\hline
\end{tabular}

\begin{tabular}{lll}
\hline Variance analysis & $\mathrm{NS}$ & $\mathrm{F}$ significant at $\mathrm{P}=0.05$
\end{tabular}


been reduced by weather conditions during spring. A number of other possible reasons may have interfered with the distribution of P levels, first of all the uptake by crop of a given amount of $\mathrm{P}$ which disappeared from the available pool.

\section{Conclusion}

The four pieces of research here reported have not demonstrated any onset of vast and worrying fluctuations of the available $\mathrm{P}$ index, neither during the spring to autumn growing season, nor during the autumn to spring period.

The appearance of significant reductions in Olsen P levels is always related to the lowering of $\mathrm{P}$ availability which is to be expected as crops gradually take up nutrients.

As a rule, it is a matter of small amounts, between tenths of a milligram and 1-1.5 mg P per kg of soil and per year. The case of the second year sampling at the MO site is an exception, as the reduction was a little larger, just over $2 \mathrm{mg} \mathrm{kg}^{-1}$.

One must always bear in mind that an unpredictable spatial variability may be expressed in an open field, which can reach a level much higher than the fluctuations recorded here. According to some authors (Ball and Williams, 1968) this kind of variability tends to mask the temporal trend and to annihilate any effort of measuring its occurrence and role analytically.

\section{References}

Ball D.F., Williams W.M. 1968. Variability of soil chemical properties in two uncultivated brown earths. J. Soil Sci. 19:379-391.

Beckett P.H.T. 1987. Spatial Variability of Soil K-status. In: Methodology in Soil-K Research, 357-380. Proceedings of the $20^{\text {th }}$ Colloquium of the International Potash Institute, Baden, Wien, 1987. International Potash Institute, Bern, Switzerland.

Blakemore M. 1966. Seasonal changes in the amount of phosphorus and potassium dissolved from soils by dilute calcium chloride solutions. J. Agric. Sci., 66:139146.

Cavazza L., Patruno A. 1997. Confronto tra concimi fosfatici. III. Influenza sul contenuto di fosforo assimilabile in terreni diversi. Riv. Agron., 31:347-360.

Cavazza L., Patruno A. 1998. A Tentative Comprehensive Model for Available Phosphorus in Soils. II. PFertilized Soils. Ital. J. Agron., 2:57-71.

Chien S.H., Savant N.K., Mokwunye U. 1982. Effect of Temperature on Phosphate Sorption and Desorption in Two Acid Soils. Soil Sci., 133:160-166.

Esilaba A.O., Eghball B., Sander D.H. 1992. Soil Test Phosphorus Availability as Affected by Time after Phosphorus Fertilization. Soil Sci. Soc. Am. J., 56:1967-1973.

Garbouchev I.P. 1966. Changes occurring during a year in the soluble phosphorus and potassium in soils under crops in rotation experiments at Rothamsted, Woburn and Saxmundham. J. Agric. Sci., 66:399-412.

Kuo S., Jellum E.J. 1987. Influence of Soil Characteristics and Environmental Conditions on Seasonal Variations of Water-Soluble Phosphate in Soils. Soil Sci., 143:257-263.

Lamarre M. Payette S. 1989. Variation saisonnière des éléments nutritifs dans un sol en production de tabac à cigarette. Can. J. Soil Sci., 69:785-798.

Lundell Y. 1987. Nutrient variation in forest soil samples due to time of sampling and method of storage. Plant Soil, 98:363-375.

Olsen S.R., Cole C.V., Watanabe F.S., Dean L.A. 1954. Estimation of available phosphorus in soils by extraction with sodium bicarbonate. U.S. Dept. Agric., Circ. No. 939.

Olsen S.R., Sommers L.E. 1982. Phosphorus. In: Page L.A., Miller R.H. and Keeney D.R. (eds.): Methods of Soil Analysis. Part 2 - Chemical and Microbiological Properties, 403-430. Agron. Monogr. No. 9, ASA, SSSA, CSSA, Madison.

Paris P., Tabaglio V., Gavazzi C. 1997. La riutilizzazione delle riserve fosfatiche in alcuni tipi di terreni emiliani. Prove agronomiche di lungo termine. Ed. Tip.Le.Co., Piacenza.

Peterson D.L., Rolfe G.L. 1982. Seasonal variation in nutrients of floodplain and upland forest soils of Central Illinois. Soil Sci. Soc. Am. J., 46:1310-1315.

Read D.W., Cameron D.R. 1979. Changes in the amount of nitrogen and phosphorus in the soil between fall and spring sampling. Can. J. Soil Sci., 59:271-276.

Smith A.M. 1959. Soil analysis and fertilizer recommendation. Proc. Fert. Soc. 57:1-40.

Soil Survey Staff 1992. Keys of Soil Taxonomy ( $5^{\text {th }}$ ed.). SMSS Techn. Monog. No. 19. Virginia Polytechnic Inst. and State University.

Tabaglio V., Gavazzi C. 2003. La riutilizzazione delle riserve fosfatiche in alcuni tipi di terreni emiliani. Un terzo quinquennio di indagine (1997-2001). Ed. Tecnograf, Reggio Emilia.

Tabaglio V., Ligabue M. 2001. Il livello dei nitrati nel terreno e le buone pratiche agricole. In: Russo E., Zavatti A. (eds.): Nitrati: acqua e suolo da salvaguardare - Prevenzione dell'inquinamento dei sistemi idrogeologici, 111-124. ARPA, Collana: I Quaderni di Arpa, publ. No. 2468. Ind. Graf. Labanti \& Nanni, Bologna.

Weaver T., Forcella F. 1979. Seasonal Variation in Soil Nutrients under Six Rocky Mountain Vegetation Types. Soil Sci. Soc. Am. J., 43:589-593. 